\title{
Percutaneous Local Ablation
}

National Cancer Institute

\section{Source}

National Cancer Institute. Percutaneous Local Ablation. NCI Thesaurus. Code C148364.

Any ablation procedure where a needle or probe is passed through the skin. 